http://jmscr.igmpublication.org/home/

ISSN (e)-2347-176x ISSN (p) 2455-0450

crossref DOI: https://dx.doi.org/10.18535/jmscr/v9i2.40

Journal Of Medical Science And Clinical Research

\title{
Clinical profile of Button Battery foreign bodies in Otolaryngology in the University of Portharcourt Teaching hospital
}

\author{
Authors \\ Dr Nwogbo A. C., Dr Oparaodu U. A. \\ ENT Department, University of Port Harcourt Teaching Hospital, Port Harcourt, Nigeria \\ *Corresponding Author \\ Dr Nwogbo Augustine
}

\begin{abstract}
Background: The appearance of button batteries in toys, and electronics appear to be a source of increased morbidity and mortality especially in the Paediatric age group. These foreign bodies observed were removed from various orifices found in the regions of the ear, nose and throat.

Method: This is a retrospective study of button batteries removed as foreign bodies accidentally lodged in the ear, nose, throat, as well as the laryngo-tracheobronchial airway, in the department of otolaryngology of the university of portharcourt teaching hospital. Case notes were retrieved from theater records, clinics and wards. Records from this case notes were put in tables and analyzed.

Results: Show button batteries in the various locations of the ear, nose, hypopharynx, larynx and oesophagus. With the majority being located in the oesophagus accounting for $40 \%$ of the cases. Complications arising from lodgement of these foreign bodies include strictures and obstructive airways.

Conclusion: Presence of button batteries as foreign bodies in the various mentioned orifices are dangerous and pose serious morbidity and even mortality if not quickly removed. Healthcare providers/parents should be aware of dangers of button battery foreign bodies lodged in any orifice.

Keywords: Button battery, Oesophagus, Anesthesia.
\end{abstract}

\section{Introduction}

Children explore their environment and sometimes may insert foreign objects into their ears, nose or into their mouth. A child may insert a foreign body into his/her orifice or insert into another child.

A foreign body is any object which is situated in a place it should not be seen. There are different types of foreign bodies which can be living or nonliving, organic or inorganic. Inorganic foreign bodies seen in the Ear, Nose and Throat (ENT) clinic ranges from toy parts, stones, beads, erasers, safety pins and button batteries just to mention a few ${ }^{1}$. The severity of the foreign body depends on the location and type.

Button batteries range between $5-25 \mathrm{~mm}$ in diameter and $1-6 \mathrm{~mm}$ in thickness. It contains a metal oxide cathode of silver oxide or mercury oxide with an alkaline solution usually $45 \%$ potassium hydroxide.

The button batteries can be found in wrist watches, remote controls, toys and electronics. Due to their shinny nature, they are attractive to children who explore their environment, or to the mentally impaired individuals, who later insert them into their ears, nose or make an attempt to 
swallow these foreign bodies. This results in an increased morbidity and possible mortality especially in the paediatric age group ${ }^{2,3}$.

With the knowledge of button batteries in the ENT which cause increased morbidity and can lead to mortality, it is important health care workers know the urgency of management of these patients and adequate education should be given to health caregivers of children.

The Aim of this study is to highlight the dangers arising from the presence of button batteries in the ear, nose and throat, as well as laryngo-tracheal airways, especially in children.

\section{Method}

This is a 4 year retrospective study on Pediatric otolaryngologic emergencies involving button batteries. The study involved the review of cases between January 2011 to January 2015 in the Ear Nose and Throat (ENT) Department of University of Portharcourt Teaching Hospital (UPTH), situated in the South-South region of Nigeria with patient load from neighboring states.

Information was retrieved from patient's notes in the medical and theater records of the hospital, after sorting from the departmental register and obtaining permission from the relevant hospital authorities. All relevant cases involving button batteries were reviewed and information analyzed by a simple descriptive method.

Data recorded were gender, site of lodgement, complications and method of anesthesia presented on tables as shown in results.

\section{Results}

There were a total of 25 cases of button batteries (as foreign bodies) during the period under review. These Foreign bodies were located in the ear, nose, hypopharynx, oesophagus and the larynx. The most common site was the oesophagus which accounts for $40 \%$ of the cases, with the least area located in the ear and hypopharynx both recording $8 \%$ each. There were more males (17) $(\mathbf{6 8 \%})$ than females $(\mathbf{8})(\mathbf{3 2 \%})$ in this review on button batteries in the ENT department of UPTH.

Majority of the foreign bodies in the nose were removed in the clinic, however 2 cases located in the nose and button batteries located in the other sites were removed under general anesthesia. The types of complications as a result of the button batteries were noted (table 3 )

Table I: Total no. of cases

\begin{tabular}{|l|c|c|c|}
\hline Site & $\begin{array}{c}\text { No. of cases } \\
(\boldsymbol{\%})\end{array}$ & Male (n) & Female (n) \\
\hline Nose & $7 \quad(28 \%)$ & 5 & 2 \\
\hline Larynx & $4(16 \%)$ & 3 & 1 \\
\hline Oesophagus & $10(40 \%)$ & 7 & 3 \\
\hline Ear & $2(8 \%)$ & 1 & 1 \\
\hline hypopharynx & $2(8 \%)$ & 1 & 1 \\
\hline $\begin{array}{l}\text { Total no. } \\
\text { of cases }\end{array}$ & $\mathbf{2 5 ( 1 0 0 \% )}$ & $\mathbf{1 7 ( 6 8 \% )}$ & $\mathbf{8 ( 3 2 \% )}$ \\
\hline
\end{tabular}

Table II: Site and method of removal

\begin{tabular}{|l|c|c|}
\hline Site & $\begin{array}{c}\text { Removed under } \\
\text { anaesthesia }\end{array}$ & $\begin{array}{c}\text { Removed in } \\
\text { consulting room }\end{array}$ \\
\hline Nose & 2 & 5 \\
\hline Larynx & 4 & - \\
\hline Oesophagus & 10 & - \\
\hline Ear & 2 & - \\
\hline Hypopharynx & 2 & - \\
\hline
\end{tabular}

Table III Complications associated with button batteries

\begin{tabular}{|l|c|}
\hline Septal perforation & 2 \\
\hline Laryngeal stenosis & 3 \\
\hline Oesophageal stricture & 2 \\
\hline Tympanic membrane perforation & 1 \\
\hline Mucosal ulceration/necrosis & 4 \\
\hline No complications observed & 13 \\
\hline Total & 25 \\
\hline
\end{tabular}

\section{Discussion}

Button batteries (bb) have different sizes, which can be inserted in various parts of the body ${ }^{2}$. This can get impacted resulting in pressure necrosis, fistula formation, increased morbidity and death from complications. In our study, two cases had esophageal stricture (Table III) ${ }^{3,4,5,6}$. The destructive natures of the button batteries on tissues make it an emergency and requires urgent removal. 
Bhosale et al in a case report had tracheoesophageal fistula in a two month old child.

Button batteries when exposed to moisture may cause leakage of electrolytes which penetrates deep into the tissue producing liquefactive necrosis. This results in dissolution of proteins and collagen, saponification of lipids, dehydration of tissue cells and consequential extensive tissue damage $^{7-11}$. We did not record any case of perforation, however, Shabino et al in their study recorded cases of esophageal perforation ${ }^{7,9,11}$. Majority of the button batteries were located in the oesophagus (table I).

These findings were also noted by Mohamed et al in their button battery foreign bodies in children, hazard, management and recommendations ${ }^{13,14,15}$. These could be explained by poor swallowing reflexes in children.

In this review the button battery foreign bodies reported in the ENT clinic of UPTH, majority of this foreign body were located in the oesophagus. This is probably due to the habit of children putting things in their mouth while they explore their environment and majority of the foreign bodies can be easily inserted into their mouth, which may accidentally get aspirated or swallowed $^{12,13}$.

When the foreign body gets impacted it becomes more difficult to remove and may result in foreign body removal in the theater under general anaesthesia $^{14-17}$. The administration of general anesthesia with endotracheal intubation is important with impacted foreign body removals in the nose and the throat as adequate protection of the airway is important to prevent bleeding and secretions into the airway resulting in laryngeal spasm, as well as the foreign body being accidentally dislodged into the airway ${ }^{14-17}$.

Thus, the majority of these foreign bodies were removed under GA with adequate precautions taken to protect the airway. This may involve having a tracheostomy done in the case of an upper airway obstruction for a foreign body in the larynx. In the present study, tracheostomy was performed for laryngeal button battery foreign bodies. Methods of removal were through rigid endoscopes, under anesthesia as recorded in table II. Same methods were used in the various reports compared with present study, especially in esophageal foreign bodies where endotracheal intubation became mandatory ${ }^{17,18,19}$.

Complications due to the foreign body may arise, more so because of the nature of the foreign body (ref 1) which may require an esophagram to assess esophageal stenosis and fistula formation ${ }^{18}$.

In this review, there were a total of 12 complications accounting for $48 \%$ of the total number of cases reviewed. This may be due to the destructive nature of the foreign body involved or pressure on the surrounding structures ${ }^{19-22}$.

With the knowledge of button batteries in the ENT which cause increased morbidity and can lead to mortality, it is important health care workers know the urgency of management of these patients and adequate education should be given to caregivers of children.

In Conclusion, the presence of button batteries as foreign bodies in various orifices is dangerous and urgent removal is mandatory to prevent morbidity and mortality. Healthcare providers/parents must be educated on dangers of button batteries as foreign bodies. Toys and various instruments of recreation powered by button batteries should be removed from children.

\section{References}

1. Oreh AC, Folorunsho D, Ibekwe TS. Actualities of management of aural, nasal and throat foreign bodies. Annals of medical health sciences research. 2015; 5(2):108-14

2. Marshall J, Williamson K. Prolonged esophageal button battery impaction in a 15 month old : A case report J Family medicine disease prevention. 2016,2 (5) 2:004

3. Bhosale M, Patil S, Aathwale H. Impacted button battery causing acquired 
tracheoesophageal fistula in a 2 month- old infant. Journal of clinical neonatology. 2016; 5 (4) 268-70

4. Yuca K, Yuca SA, Caksen H. Aural live foreign bodies in children. J Emerg Med 2003;25;102-4

5. Ansley JF, Cunningham MJ. Treatment of aural foreign bodies in children. Pediatrics 1998;101:638-41

6. Ologe FE, Dunmade AD, Afolabi OA. Aural Foreign bodies in children. Indian $\mathrm{J}$ Pediatr 2007;74;755-8

7. Premanchandra DJ, Mc RAE d. Severe tissue destruction in the ear caused by alkaline button battery. Postgraduate medical journal 1990;66(771):52-3

8. Fernando $\mathrm{P}$. perforation of nasal septum due to button battery lodging in nose. $\mathrm{Br}$ Med J 1987,294:742-743

9. Shabino CL, Feinberg esophageal perforation secondary to alkaline battery ingestion. $\mathrm{J}$ Am Coll Emerg Med 1979,8;360 -362

10. Votteler TP, Nash JC, Butledge JC. The hazards of ingested alkaline disk batteries in children. JAMA 1983, 249 :2504-06

11. Honck JC, De Angelo L, Jacob RA. The dermal chemical response to alkali injury. Surgery 1962,51:503-507

12. Chan TC,Ufberg J, Harrigan RA, Vike GM. Nasal foreign body removal. The Journal of Emergency Medicine.2004; 26(4):441-5

13. Mohammed HT, Waleed MB, Sherif A. Button Battery foreign bodies in children: Hazards, management and recommendation. Biomed research international volume 2013, Article ID 846091

14. Kalan A, Tariq M. Foreign bodies in the nasal cavities ; a comprehensive review of the aetiology, diagnostic pointers and therapeutic measures. Postgraduate medical journal $2000 ; 76$ (898):484-7
15. Esclamado RM, Richardson MA. Laryngotracheal foreign bodies in children. A comparison with bronchial foreign bodies. Am J Dis Child 1987;141:259-62

16. Robinson PJ. Laryngeal foreign bodies in children; First stop before the right main bronchus. J Paediatr Child Health 2003;39;477-9

17. Gautam V, Phillips J , Bowmer h, Reichl M. Foreign body in the throat $\mathrm{J}$ Accid Emerg 1994;11:113-5

18. Silva AB, Muntz HR, Clary R. Utility of conventional radiography in the diagnosis and management of paediatric airway foreign bodies. Ann Otol Rhinol Laryngol 1998;107:834-8

19. Jatana KR, Litovitz T, Reilly JS , Koltai PJ, Rider $\mathrm{G}$ et al. Paediatric button battery injuries: 2013 task force update. International journal of Paediatric Otorhinolaryngology 77: 1392-1399

20. Mc Rae D, Premachandra DJ, Gatland DJ . Button battery in the ear,nose and cervical oesophagus : a destructive foreign body. The Journal of otolaryngology. 1989;18 (6):317-9

21. Bakshi SS, Coumare VN, Priya M,Kumar S. Long term complications of button battery in the nose. The journal of emergency medicine.2016;50(3):485-7

22. Litovitz TL. Button battery ingestion : a review of 56 cases. JAMA 198313 ;249(8):2495-500

23. Brumbaugh DE, Colson SB, Sandoral JA, Karres FM, Bealer JF, Litovitz T, Kramer RE. Management of button battery induced hemorrhage in children. Journal of pediatric gastroenterology and nutrition 2011; 52(5):585-9. 